\title{
PYTANIA O PRZYSZŁOŚĆ GOSPODARKI PRZESTRZENNEJ W POLSCE
}

\section{(Po 13 latach obowiązywania regulacji prawnych z 2003 r.)}

\section{WSTĘP}

Trzynaście lat prowadzenia gospodarki przestrzennej w Polsce, jak mówia prawnicy, pod rządami ustawy z 27 marca 2003 r. o planowaniu i zagospodarowaniu przestrzennym ${ }^{1}$ jest, jak się wydaje, wystarczająco długim okresem, aby ocenić skutki, jakie w zagospodarowaniu przestrzennym przynoszą regulacje prawne w niej zawarte. Ocena tych skutków jest także ważna i z tego powodu, że trwaja prace nad nowym dokumentem prawnym, regulujacym - pozostając przy terminologii z 2003 r. - planowanie i zagospodarowanie przestrzenne. W gruncie rzeczy chodzić jednak powinno o prawne uregulowanie w ramach nowej ustawy tych wszystkich działań, które składają się na gospodarkę przestrzenna, w szerokim tego rodzaju rozumieniu. Refleksja nad efektami stosowania w praktyce postanowień wspominanej i aktualnie obowiązującej u.p.z.p. jest także ważna w związku z pracami nad innym dokumentem prawnym, ważnym z punktu widzenia gospodarki przestrzennej, tj. nad „kodeksem budowlanym”. Zupełnie innym zagadnieniem jest potrzeba prawnego uregulowania problematyki rozwoju społeczno-gospodarczego, zwłaszcza kiedy to ten rozwój jest zasadniczym generatorem zmian w zagospodarowaniu przestrzennym. W takiej sytuacji być może sensowną rzeczą byłoby opracowanie i uchwalenie przez Sejm dokumentu o nazwie „ustawa o planowaniu rozwoju”, zwłaszcza kiedy coraz bardziej dojrzałe struktury samorządu terytorialnego sa zobligowane, na mocy obowiąującego prawa, do dbałości zarówno o rozwój społeczno-gospodarczy, jak i przestrzenny². Za rozważeniem przygotowania takich właśnie regulacji prawnych (planowanie rozwoju) przemawia także coraz mocniej akcentowana potrzeba powrotu do idei planowania zintegrowanego (opracowywanie planów zintegrowanych rozwoju jedno-

1 Dz. U. 2003, Nr 80, poz. 717 ze zm. (dalej jako: „u.p.z.p.” lub „ustawa”).

${ }^{2}$ Ustawa o samorządzie gminnym z 8 marca 1990 r., Dz. U. Nr 16, poz. 95 ze zm. (dalej jako: u.s.g.) - art. 7; ustawa o samorządzie wojewódzkim z 5 czerwca 1998 r., Dz. U. Nr 91 ze zm. (dalej jako: u.s.w.) - art. 11 ust. 1 oraz ustawa o planowaniu i zagospodarowaniu przestrzennym z 27 marca 2003 r. 
stek terytorialnych, względnie zintegrowanie procesu planowania). Za takim rozwiązaniem przemawia także logiczna konieczność nawiązania w różnych dokumentach planistycznych do strategii rozwoju społeczno-gospodarczego, potwierdzona $\mathrm{w}$ istniejących regulacjach prawnych ${ }^{3}$. Także $\mathrm{w}$ literaturze naukowej często podkreśla się konieczność współdziałania władzy publicznej różnych szczebli w działaniach na rzecz rozwoju ${ }^{4}$. Idea „zintegrowanego rozwoju” zapisana została także w dokumentach Unii Europejskiej dotyczacych polityki regionalnej i polityki miejskiej. Te ostatnie zagadnienia wykraczaja jednak poza zakres rzeczowy niniejszego opracowania, obejmującego przede wszystkim charakterystykę polskiego systemu planowania przestrzennego i ocenę skutków jego funkcjonowania i nie będą w tym miejscu przedstawiane. Warto przy tej okazji pamiętać, że planowanie przestrzenne jest pierwszym etapem gospodarki przestrzennej - jest etapem prospekcyjnym względem gospodarowania przestrzenią i gospodarowania w przestrzeni (gospodarki przestrzennej w ścisłym tego słowa znaczeniu), czego końcowym efektem jest zagospodarowanie przestrzenne ${ }^{5}$.

\section{POLSKI SYSTEM PLANOWANIA PRZESTRZENNEGO W ŚWIETLE USTAWY Z 27 MARCA 2003 R. O PLANOWANIU I ZAGOSPODAROWANIU PRZESTRZENNYM}

\section{Elementy systemu}

Mimo generalnie krytycznej oceny planowania przestrzennego zgodnie z postanowieniami u.p.z.p., dokument ten (ustawa) określa jednak polski system planowania i gospodarki przestrzennej. Oczywiście można tworzyć rożne modele systemu planowania - i taki, w miarę sensowny model, powinien być rezultatem oczekiwanych zmian ${ }^{6}$. Tak jak każdy system, tak i system planowania przestrzennego w Polsce tworzą elementy, tj. przedmioty planowania, podmioty planujace oraz dokumenty planistyczne, relacje między tymi elementami oraz otoczenie systemu planowania.

Przedmiotami planowania (także gospodarki przestrzennej) w Polsce sa jednostki terytorialnego podziału kraju, tj. kraj, województwo i gmina lub wyodrębnione części gminy (obszary, dla których opracowywane są miejscowe plany zagospodarowania przestrzennego). W pewnym sensie przedmiotem gospodarki przestrzennej są także obszary metropolitalne, dla których opra-

${ }^{3}$ U.p.z.p.

${ }^{4}$ K. Kokocińska, Prawny mechanizm prowadzenia polityki rozwoju $w$ zdecentralizowanych strukturach władzy publicznej, WN UAM, Poznań 2014; eadem, Wspótdziałanie podmiotów władzy publicznej na rzecz rozwoju, „Ruch Prawniczy, Ekonomiczny i Socjologiczny” 77, 2015, z. 3, s. $181-191$.

5 J. Parysek, Wprowadzenie do gospodarki przestrzennej, WN UAM, Poznań 2006.

${ }_{6}$ Model polskiego systemu planowania przestrzennego wg stanu prawnego na dzień 1 grudnia 2001 r. przedstawia Z. Niewiadomski w publikacji Planowanie przestrzenne. Zarys systemu, LexisNexis, Warszawa 2001. 
cowywane jest autonomiczne studium uwarunkowań i kierunków zagospodarowania przestrzennego, oraz tzw. miejskie obszary funkcjonalne ośrodków wojewódzkich, jednakże plan ich zagospodarowania jest częścią planu zagospodarowania przestrzennego województwa. Ustawodawca wyróżnia także inne obszary funkcjonalne, nie wskazuje jednak na ich przedmiotowy charakter w zakresie planowania przestrzennego i gospodarki przestrzennej (por. rozdz. 2a i 4a u.p.z.p.). W innym miejscu używa jednak terminu „obszary problemowe", nie podając z kolei wzajemnych relacji wyróżnionych kategorii pojęciowych. Podmiotami planowania (gospodarki przestrzennej) w Polsce sa odpowiednio: Rada Ministrów - dla kraju jako całości (wykonawczo minister właściwy dla spraw rozwoju regionalnego), samorządy wojewódzkie (sejmiki) - dla województw oraz rady gminne - dla obszarów gmin. Nowym podmiotem gospodarki przestrzennej jest w pewnym sensie także bliżej nieokreślony „związek metropolitalny”. Jak to wynika z zapisu u.p.z.p., są to podmioty odpowiedzialne przede wszystkim za politykę przestrzenną na obszarze odpowiedniej jednostki terytorialnego podziału kraju (rozdz. 1 art. 3 u.p.z.p.). Ustawa wspomina także o władzach samorządowych powiatów, których jednym z zadań jest prowadzenie analiz i studiów z zakresu zagospodarowania przestrzennego, co trudno jest uznać za podmiotowość w zakresie zarówno planowania przestrzennego, jak i gospodarki przestrzennej.

Można mówić o siedmiu podstawowych kategoriach dokumentów planistycznych polskiego systemu planowania przestrzennego o różnym charakterze i znaczeniu. Są to: na szczeblu krajowym - (1) koncepcja przestrzennego zagospodarowania kraju, na szczeblu wojewódzkim - (2) plan zagospodarowania przestrzennego województwa, (3) studium uwarunkowań i kierunków zagospodarowania przestrzennego obszaru związku metropolitalnego, (4) plan zagospodarowania przestrzennego miejskiego obszaru funkcjonalnego ośrodka wojewódzkiego, a także opracowywany, co najmniej raz na 20 lat (5) „audyt krajobrazowy”, dokument nieznany dotychczas w polskiej praktyce planistycznej oraz na szczeblu gminnym (lokalnym) - (6) studia uwarunkowań i kierunków zagospodarowania przestrzennego gmin oraz (7) miejscowe plany zagospodarowania przestrzennego. Zmiany w zagospodarowaniu przestrzennym na obszarze gminy wprowadza także tzw. administracyjna decyzja o „ustaleniu warunków zabudowy i zagospodarowania”, choć trudno ją nazwać dokumentem planistycznym ${ }^{8}$. Koncepcja przestrzennego zagospodarow ania kraju (KPZK) jest zbiorem kierunków polityki przestrzennej państwa i pewną dość słabo, w stosunku do dawnych planów krajowych, zarysowana wizją zagospodarowania przestrzennego. Jako dokument nie ma mocy prawnej, pełni przede wszystkim funkcję koncepcyjna, strategiczną i informacyjna. Jest przede wszystkim ogólną wizją stanu zagospodarowania kraju, jaki powinien zostać osiagnięty w zakładanym wymiarze czasowym w wyniku realizacji zapisanych w tym dokumencie kierunków działań. Podobne funkcje pełni plan zagospodarowania przestrzennego województwa,

7 Związek metropolitalny definiuje ustawa z 9 października 2015 r. o związkach metropolitalnych, Dz. U. 2015, poz. 1890.

${ }^{8}$ Rozporządzenie Ministra Infrastruktury z 26 sierpnia 2003 r., Dz. U. Nr 164, poz. 1588. 
będący koncepcja zagospodarowania przestrzennego konkretnego regionu. Ważną częścią tego planu jest plan zagospodarowania przestrzennego miejskiego obszaru funkcjonalnego ośrodka wojewódzkiego, przede wszystkim z uwagi na toczące się procesy suburbanizacji i wykształcanie się struktur metropolitalnych. W pewnym sensie znanym z metodologii planowania tzw. studium przed planowym, ograniczajacym przyjmowane w planie wojewódzkim rozwiązania przestrzenne, będzie prawdopodobnie audyt krajobrazowy - nowy dokument polskiej praktyki planistycznej. Plany zagospodarowania przestrzennego województw (chyba w mniejszym stopniu niż KPZK), pełnią także funkcję strategiczna, jednak bardziej koncepcyjna i decyzyjna. Oba te dokumenty planistyczne szczebla regionalnego (audyt i plan) sa jedynie tzw. dokumentami kierownictwa wewnętrznego, będąc wytycznymi dla władz samorządowych województwa w zakresie polityki i gospodarki przestrzennej.

Nie jest aktem prawa także ramowe studium uwarunkowań i kierunków zagospodarowania przestrzennego obszaru związku metropolitalne go. Tak na dobrą sprawę u.p.z.p. nie informuje, jakiego rodzaju podmiotem gospodarki przestrzennej jest związek metropolitalny. Dokumentem, na podstawie którego kształtować można i należy politykę przestrzenna gminy, jest studium uwarunkowań i kierunków zagospodarowania przestrzennego gminy. Jest to zbiór uwarunkowań oraz sformułowanych na tej podstawie kierunków zagospodarowania przestrzennego. Jest to także dokument kierownictwa wewnętrznego, choć całkiem inny co do charakteru i treści w stosunku do przywołanych poprzednio. Teoretycznie o przyszłym kształcie zagospodarowania przestrzennego obszaru gminy przesądzać powinien miejscowy plan zagospodarowania przestrzennego, będący aktem prawa miejscowego obowiązującym powszechnie mieszkańców i podmioty gospodarcze obszaru gminy. Plan ten pełni przede wszystkim funkcje decyzyjne i realizacyjne. W świetle obowiąującego prawa gospodarki przestrzennej i jego spójności jest to jedyna podstawa dokonywania zmian w zagospodarowaniu przestrzennym ${ }^{9}$. Niestety, praktycznie o zagospodarowaniu terenu w coraz większym stopniu decydują administracyjne decyzje dotyczące warunków zabudowy zagospodarowania, a nie plany. Należy w tym miejscu dodać, że ustawodawca zakłada, iż na wszystkich wyróżnionych poziomach gospodarki przestrzennej wykonywane będą opracowania przydatne, a nawet niezbędne dla prowadzenia polityki przestrzennej, takie jak: analizy, studia, programy, prognozy, a także koncepcje. Ilość i zakres tego rodzaju opracowań pozostaje, jak się wydaje, sprawą decyzji jednostek planujących (władz samorządowych).

\section{Relacje systemowe}

Wymienione powyżej dokumenty planistyczne tworzą układ hierarchiczny z ustawowo określoną zasadą nadrzędności - podrzędności. Generalnie rzecz ujmując, założenia koncepcji przestrzennego zagospodarowania kra-

9 Z. Leoński, M. Szewczyk, Zasady prawa budowlanego i zagospodarowania przestrzennego, Poznań-Bydgoszcz 2002, s. 54-60. 
ju muszą zostać uwzględnione w planach zagospodarowania przestrzennego województw i gmin, natomiast zapisy planu zagospodarowania województwa muszą zostać uwzględnione w miejscowych planach zagospodarowania gmin wchodzących w skład danego województwa. Dotyczy to w szczególny sposób inwestycji celu publicznego. Jest to droga do zagwarantowania wspomnianej już spójności systemu planowania przestrzennego. Sa jeszcze tego rodzaju relacje, które zobowiązują do uwzględnienia wyników audytu krajobrazowego $\mathrm{w}$ planie zagospodarowania przestrzennego województwa oraz treści tegoż planu w ramowym studium uwarunkowań i kierunków zagospodarowania przestrzennego obszaru związku metropolitalnego i planu zagospodarowania przestrzennego miejskiego obszaru funkcjonalnego ośrodka wojewódzkiego.

Wyżej wymienione relacje zostały w pewnym sensie sformalizowane w procedurze dokonywania niezbędnych uzgodnień i ustaleń związanych z pracami planistycznymi. Już np. studia uwarunkowań i kierunków zagospodarowania przestrzennego gmin muszą zostać uzgodnione z zarządem województwa (na etapie projektu), w zakresie ich zgodności z planem zagospodarowania przestrzennego województwa (art. 11 u.p.z.p.). Uchwalane studium jest następnie przekazywane wojewodzie, który ocenia jego zgodność z obowiązującymi przepisami prawnymi. Podobna procedura dotyczy planu miejscowego, którego projekt jest uzgadniany z wojewoda, zarządem województwa, a także zarządem powiatu, przede wszystkim w zakresie zadań rządowych i samorządowych (art. 17 u.p.z.p.). Uchwalony plan przedstawiany jest następnie wojewodzie celem stwierdzenia jego zgodności z prawem (art. 20 u.p.z.p.). Proces uzgodnień i akceptacji dotyczy także planu wojewódzkiego. Przygotowany projekt planu musi uzyskać pozytywną opinię wojewódzkiej komisji urbanistyczno-architektonicznej. Wymagane są także opinie „właściwych instytucji i organów”, w tym od wojewody, zarządów powiatów oraz wójtów gmin, burmistrzów i prezydentów miast położonych na terenie województwa, a także od organów administracji publicznej na terenach przyległych do granic województwa. Projekt planu przedstawiony jest następnie właściwemu ministrowi do spraw budownictwa, gospodarki przestrzennej i mieszkaniowej w celu stwierdzenia jego zgodności z koncepcja przestrzennego zagospodarowania kraju. Tego rodzaju rozwiązania w niczym nie naruszaja samodzielności planistycznej gminy ani jej władztwa planistycznego, które przysługuje jedynie władzom tego rodzaju jednostki terytorialnej, jaka jest gmina (miejska, miejsko-wiejska, wiejska ${ }^{10}$. Oczywiście na władze państwowe spada z jednej strony obowiązek prowadzenia polityki przestrzennej w skali kraju, a z drugiej - koordynacja realizacji celów publicznych o ponadlokalnym znaczeniu, co nazywa się zasadą właściwości administracji rządowej w kształtowaniu polityki przestrzennej państwa $^{11}$. Można by zatem przyjąć, że relacje systemowe w polskim systemie planowania są efektem decentralizacji zadań oraz spójności systemu, w którym każdy ze szczebli planowania przestrzennego (gospodarki przestrzennej), ma swoje określone zadania i pełni określone funkcje $\mathrm{e}^{12}$.

${ }_{10}$ Z. Niewiadomski, op. cit.; J. Parysek, op. cit.

11 Z. Niewiadomski, op. cit.

12 Z. Leoński, M. Szewczyk, op. cit.; Z. Niewiadomski, op. cit.; J. Parysek, op. cit. 
Powyżej opisane relacje, aczkolwiek jedynie najważniejsze spośród zapisanych w u.p.z.p., mają charakter wewnątrzsystemowy (dotyczą systemu planowania). W istniejaccym systemie planowania przestrzennego uwzględniać jednak należy tzw. relacje zewnętrzne, które wiążą elementy systemu planowania przestrzennego z elementami innych systemów o charakterze planistycznym, wchodzących w skład otoczenia ('środowiska) polskiego systemu planowania przestrzennego. Sa to przede wszystkim relacje łączące opracowywane plany zagospodarowania przestrzennego oraz studia uwarunkowań i kierunków zagospodarowania (w mniejszym stopniu audyty krajobrazowe) z strategiami rozwoju społeczno-gospodarczego jednostek terytorialnych oraz planami dotyczacymi kształtowania i ochrony środowiska, ustawą o rewitalizacji, o zwiąkach metropolitalnych i innymi jeszcze regulacjami prawnymi. Ważność i znaczenie tego rodzaju relacji wynika z faktu, że to rozwój społeczno-gospodarczy generuje potrzeby $\mathrm{w}$ zakresie zagospodarowania przestrzennego, a właściwości, jakość oraz stan środowiska wyznaczają ramy możliwych rozwiązań (co podkreśla m.in. zapis o zakresie rzeczowym audytu - art. 38a u.p.z.p.). Na konieczność kształtowania tych kategorii relacji zwraca uwagę ustawodawca w omawianej ustawie.

\section{Otoczenie systemu}

Trudno jest w sposób jednoznaczny opisać otoczenie czy środowisko systemu planowania. Dla podmiotów planujących otoczeniem są inne, zewnętrzne podmioty planujące. Dla gminy są to inne gminy, a także województwo, w skład którego wchodzi dana gmina, oraz kraj. Dla województw otoczeniem sa inne województwa oraz kraj, natomiast dla kraju - państwa ościenne, kraje Unii Europejskiej, pozostałe państwa kontynentu. Dla gospodarki przestrzennej i planowania przestrzennego otoczeniem jest gospodarka w ogóle i gospodarka przestrzenna zewnętrznych w stosunku do danej jednostki, jednostek terytorialnego podziału kraju. Otoczeniem dla tworzonych dokumentów planistycznych zagospodarowania przestrzennego sa inne, opracowywane dokumenty planistyczne dotyczące przedmiotu planowania przestrzennego, przede wszystkim strategie rozwoju społeczno-gospodarczego, programy gospodarcze, lokalne programy rewitalizacji, plany i programy kształtowania i ochrony środowiska itp.

W całym opisanym powyżej systemie planowania na szczególne podkreślenie zasługuje przede wszystkim gmina, w której granicach tak naprawdę ma miejsce realizacja gospodarki przestrzennej. Władztwo planistyczne i kompetencyjne w dziedzinie określenia przez władze gminy przeznaczenia terenu na określone cele jest jednoznaczne i żaden inny podmiot gospodarki przestrzennej nie ma takich uprawnień. Wprawdzie w studium uwarunkowań i kierunków zagospodarowania przestrzennego gminy, a niekiedy i w miejscowych planach zagospodarowania przestrzennego, uwzględnia się założenia polityki przestrzennej państwa i koncepcji zagospodarowania przestrzennego województwa (także innych dokumentów planistycznych), to jednak konkretyzacja celów ponadlokalnych wraz z celami lokalnymi odbywa się w gminie. Tak 
więc $\mathrm{w}$ polskim, w sumie nie najlepiej zaprojektowanym, systemie planowania przestrzennego gmina jest podstawowym elementem tego systemu, zarówno w odniesieniu do planowania przestrzennego, jak i do gospodarki przestrzennej. Jest jedynym podmiotem działającym z mocy prawa i przy wykorzystaniu prawa (miejscowy plan zagospodarowania przestrzennego).

\section{ZAKRES RZECZOWY I ROLA PODSTAWOWYCH DOKUMENTÓW PLANISTYCZNYCH}

\section{Koncepcja przestrzennego zagospodarowania kraju}

Zgodnie z art. 47 u.p.z.p., koncepcję przestrzennego zagospodarowania kraju, uwzględniająca cele zawarte $\mathrm{w}$ rządowych dokumentach strategicznych, opracowuje minister właściwy do spraw rozwoju regionalnego. Koncepcja ta uwzględniać powinna zasady zrównoważonego rozwoju wynikające z przyrodniczych, kulturowych, społecznych i ekonomicznych uwarunkowań rozwoju. Zgodnie z regulacja art. 47 ust. 2 u.p.z.p.: „Koncepcja przestrzennego zagospodarowania kraju określa uwarunkowania, cele i kierunki zrównoważonego rozwoju kraju oraz działania niezbędne do jego osiagnięcia [...]”. W sposób szczególny uwzględnia problematykę krajowej sieci osadniczej, zagadnienia ochrony środowiska i zabytków, rozmieszczenie infrastruktury technicznej i społecznej o znaczeniu krajowym i międzynarodowym oraz strategicznych zasobów wodnych. Wskazuje ponadto obszary problemowe, w tym wymagajace szczegółowych studiów i planów.

\section{Audyt krajobrazowy (wojewódzki)}

Jest to nowe narzędzie planowania przestrzennego na szczeblu wojewódzkim. Dokument ten (audyt) powinien być opracowany nie rzadziej niż raz na 20 lat i poprzedzać opracowanie i uchwalenie planu wojewódzkiego (art. 38a ust. 2 u.p.z.p.). „Audyt krajobrazowy identyfikuje krajobrazy występujące na całym obszarze województwa, określa ich cechy charakterystyczne oraz dokonuje oceny ich wartości”. W szczególności: określa: krajobrazy występujące na obszarze danego województwa, wskazuje lokalizację i wyznacza granice: parków kulturowych, parków narodowych, rezerwatów przyrody, parków krajobrazowych, obszarów chronionego krajobrazu, obiektów z listy Światowego Dziedzictwa UNESCO, obszarów Sieci Rezerwatów Biosfery UNESCO itp. Wskazuje ponadto zagrożenia dla możliwości zachowania wartości krajobrazów i obiektów, zawiera rekomendacje i wnioski dotyczace kształtowania i ochrony krajobrazów (także krajobrazów w obrębie wyróżnionych obszarów lub obiektów) w szczególności przez wskazanie obszarów, które powinny zostać objęte formami ochrony przyrody (o których mowa w ustawie o ochronie przyrody) oraz wskazuje lokalne formy architektoniczne zabudowy w obrębie krajobrazów (art. 38a). Rekomendacje i wnioski, o których mowa powyżej, nie mogą być sprzeczne z celami i sposobami ochrony obszarów i obiektów, o których mowa 
w ustawie o ochronie przyrody ${ }^{13}$ lub ustawie o ochronie zabytków i opiece nad zabytkami ${ }^{14}$. Ponadto audyt krajobrazowy może wskazywać te obszary objęte formami ochrony przyrody, które ze względu na znaczący spadek wartości krajobrazu wymagaja pogłębionej analizy zasadności ich dalszej ochrony (art. 38a). Celem opracowania audytów krajobrazowych Rada Ministrów w drodze rozporządzenia określi szczegółowe zasady ich opracowania oraz zakres rzeczowy. Opracowany audyt ma na celu „zapewnienie właściwej ochrony krajobrazów i możliwości ich kształtowania oraz konieczność zachowania krajobrazów będących źródłem tożsamości narodu polskiego". Projekt audytu sporządza zarząd województwa, a po przeprowadzeniu procedury opiniowania i konsultacji uchwala sejmik wojewódzki (art. 38b ust. 2).

\section{Plan zagospodarowania przestrzennego województwa}

Uchwałę o przystapieniu do sporządzenia planu zagospodarowania przestrzennego województwa podejmuje sejmik wojewódzki (art. 39 ust. 1), a dokument ten sporządza zarząd województwa (art. 39 ust. 2). W planie zagospodarowania przestrzennego województwa określa się w szczególności: sieć osadniczą i jej elementy, wraz ich powiązaniami infrastrukturalnymi i komunikacyjnymi, system obszarów chronionych (środowiska, przyrody i krajobrazu kulturowego, uzdrowisk, dziedzictwa kulturowego, zabytków oraz dóbr kultury współczesnej), rozmieszczenie ponadlokalnych inwestycji celu publicznego, granice i zasady zagospodarowania obszarów funkcjonalnych o znaczeniu ponadregionalnym i regionalnym, obszary szczególnego zagrożenia powodzia, granice terenów zamkniętych i ich stref ochronnych oraz obszary występowania udokumentowanych złóż kopalin i udokumentowanych kompleksów podziemnego składowania dwutlenku węgla (art. 39 ust. 3)”15.

Jak to już napisano, w planie zagospodarowania przestrzennego województwa uwzględnia się ustalenia koncepcji przestrzennego zagospodarowania kraju, w tym zwłaszcza inwestycje celu publicznego o znaczeniu ponadlokalnym (art. 39 ust. 5). Minister właściwy do spraw rozwoju regionalnego określa $\mathrm{w}$ drodze rozporządzenia wymagany zakres projektu planu zagospodarowania przestrzennego województwa, uwzględniając w szczególności wymogi dotyczące materiałów planistycznych, skali opracowań kartograficznych, stosowanych oznaczeń, nazewnictwa, standardów oraz sposobu dokumentowania prac planistycznych (art. 40).

Częścia planu zagospodarowania przestrzennego województwa jest plan zagospodarowania przestrzennego miejskiego obszaru funkcjonalnego ośrodka wojewódzkiego, który może także obejmować również tereny leżące poza granicami miejskiego obszaru funkcjonalnego (art. 39 ust. 6 i 39 ust. 7). Należy w tym miejscu podkreślić, że przed uchwaleniem

\footnotetext{
${ }^{13}$ Ustawa z 16 kwietnia 2004 r. o ochronie przyrody, Dz . U. 2004, Nr 92, poz. 880 ze zm.

${ }_{14}$ Ustawa z 23 lipca 2003 r. o ochronie zabytków i opiece nad zabytkami, t.jedn.: Dz. U. 2014, poz. 1446.

${ }^{15}$ Wobec uchylenia niektórych zapisów pierwotnej wersji u.p.z.p., przy wyliczaniu celów, zadań, powinności itp. zastosowano kolejność wyliczania z pominięciem uchylonych (np. pkt 5 z art. 39 ust. 2).
} 
przez sejmik planu marszałek województwa dokonuje stosownych ustaleń i uzgodnień oraz uzyskuje zapisane w u.p.z.p. opinie (art. 41). Uchwalony plan jest narzędziem realizacji polityki przestrzennej na obszarze województwa.

\section{Ramowe studium uwarunkowań i kierunków zagospodarowania przestrzennego związku metropolitalnego}

Wspomniane wyżej studium opracowuje związek metropolitalny, uwzględniając zapisy planu zagospodarowania przestrzennego województwa. Przedmiotem tego dokumentu jest „cały obszar metropolitalny” (art. 37o). W dokumencie tym określa się: zasady i obszary rozwoju systemów komunikacji i infrastruktury technicznej oraz wskazuje rozmieszczenie innych inwestycji celu publicznego o znaczeniu metropolitalnym, zasady i obszary ochrony środowiska, przyrodniczego (krajobrazu, korytarzy ekologicznych, uzdrowisk, dziedzictwa kulturowego i zabytków oraz dóbr kultury współczesnej), ustalenia wynikające z zasad rozwoju i ochrony obszarów, położonych w granicach obszaru metropolitalnego oraz maksymalne powierzchnie przeznaczone pod zabudowę, z podziałem na rodzaje zabudowy oraz gminy. Uwzględnia się przy tej okazji potrzeby i możliwości rozwojowe obszaru metropolitalnego, biorąc pod uwagę w szczególności: analizy ekonomiczne, środowiskowe i społeczne, prognozy demograficzne, możliwości finansowania przez gminy oraz związek metropolitalny inwestycji służących realizacji zadań własnych odpowiednio tych jednostek oraz bilans terenów przeznaczonych pod zabudowę.

Ustawodawca wyraźnie zaznacza, że ustalenia studium metropolitalnego obejmują jedynie elementy niezbędne dla właściwego ukierunkowania polityki przestrzennej gmin należących do związku, ze względu na spójność przestrzenną i społeczno-gospodarczą obszaru metropolitalnego. Są wiążące dla wójta, burmistrza albo prezydenta miasta przy sporządzaniu studium, choć dokument ten nie jest aktem prawa miejscowego.

\section{Dokumenty planistyczne na szczeblu gminnym (narzędzia prowadzenia polityki przestrzennej i planowania przestrzennego)}

Jak to już napisano w tym opracowaniu, jedynie władze gminne zostały wyposażone przez ustawodawce $\mathrm{w}$ tzw. władztwo planistyczne, co oznacza, że samorząd gminny został uznany za podstawowy podmiot istniejącego systemu planowania przestrzennego $\mathrm{w}$ Polsce ${ }^{16}$. Zatem stosownie do zapisu art. 1 u.p.z.p., wypracowując i przyjmując zasady kształtowania polityki przestrzennej, gmina jako jednostka samorządu terytorialnego uchwala s tu diu m uwarunkowań i kierunków zagospodarowania przestrzennego (studium), natomiast określając zakres i sposoby przeznaczenia terenu na określone cele, a także ustalając zasady zagospodarowania tych terenów oraz ich zabudowy, uchwala miejscowe plany zagospodarowania przestrzennego (miejscowy plan). Podejmuje jednak także administracyjne

${ }^{16}$ Z. Niewiadomski, op. cit., J. Parysek, op. cit. 
decyzje tzw. ustalenia warunków zabudowy i zagospodarowania. Podstawowy, w zasadzie obligatoryjny zakres rzeczowy obu dokumentów planistycznych przedstawiony został $\mathrm{w}$ tabeli 1 .

Tabela 1

Uwarunkowania i kierunki rozwoju przestrzennego oraz obligatoryjna treść planu

\begin{tabular}{|c|c|c|}
\hline \multicolumn{2}{|c|}{$\begin{array}{l}\text { Studium uwarunkowań i kierunków } \\
\text { zagospodarowania przestrzennego }\end{array}$} & \multirow{2}{*}{$\begin{array}{c}\text { Obligatoryjna treść } \\
\text { miejscowego plan } \\
\text { zagospodarowania } \\
\text { przestrzennego }\end{array}$} \\
\hline Główne uwarunkowania & Kierunki i obszary & \\
\hline $\begin{array}{l}\text { Dotychczasowe przezna- } \\
\text { czenie i uzbrojenie terenu } \\
\text { - Stan ładu przestrzennego } \\
\text { - Stan środowiska przy- } \\
\text { rodniczego oraz rolniczej } \\
\text { przestrzeni produkcyjnej } \\
\text { - Stan zabytków dziedzic- } \\
\text { twa kulturowego } \\
\text { - Warunki i jakość życia } \\
\text { mieszkańców } \\
\text { - Zagrożenia bezpieczeń- } \\
\text { stwa ludności i mienia } \\
\text { Potrzeby i możliwości } \\
\text { rozwoju gospodarczego } \\
\text { - Stan prawny gruntów } \\
\text { - Stan infrastruktury tech- } \\
\text { nicznej i systemów komu- } \\
\text { nikacji } \\
\text { - Stan gospodarki energe- } \\
\text { tycznej, wodnej, ściekowej } \\
\text { i gospodarki odpadami } \\
\text { Występowanie obiektów } \\
\text { i obszarów chronionych } \\
\text { towanytepowanie udokumen- } \\
\text { mineralnych i wód } \\
\text { i obszarów górniczych } \\
\text { - } \\
\text { - }\end{array}$ & 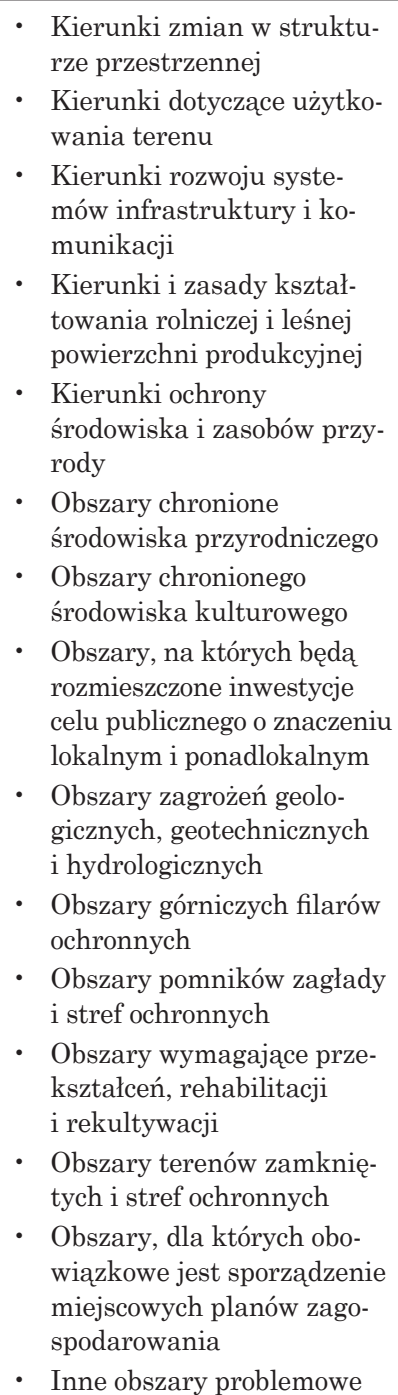 & 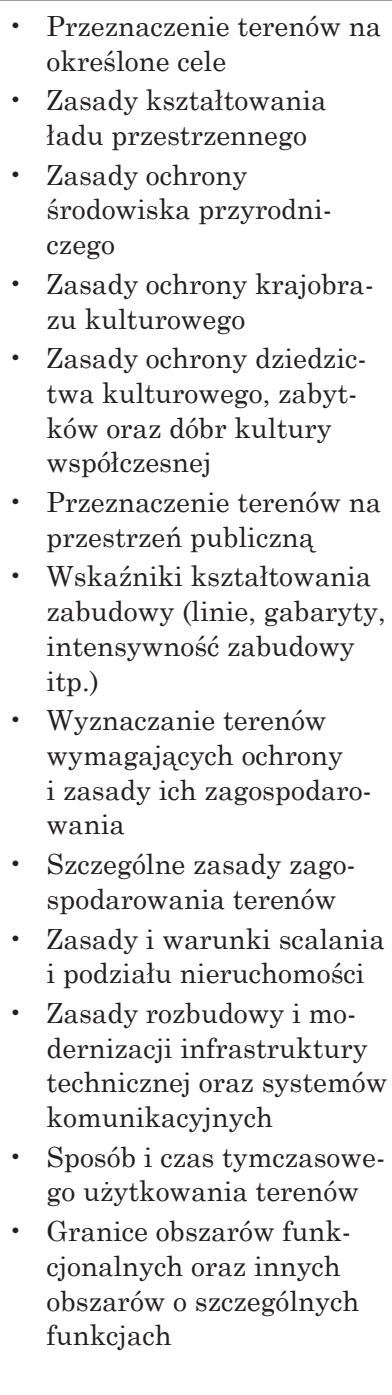 \\
\hline
\end{tabular}

Źródło: opracowanie własne na podstawie ustawy o planowaniu i zagospodarowaniu przestrzennym z 27 marca 2003 r. (wersja pierwotna z 27 marca 2003 r.) 


\subsection{Studium uwarunkowań i kierunków zagospodarowania przestrzennego}

Jak sama nazwa wskazuje, studium zawiera przede wszystkim zbiór uwarunkowań zagospodarowania oraz wynikajace z tych uwarunkowań, ale także i innych dokumentów (np. koncepcji przestrzennego zagospodarowania kraju, strategicznych dokumentów rozwoju kraju, planu zagospodarowania przestrzennego województwa, audytu krajobrazowego, strategii rozwoju społeczno-gospodarczego województwa, strategii rozwoju gminy i innych) kierunki zagospodarowania przestrzennego. Ten obligatoryjny dokument (studium) nie może być jednak podstawą żadnych decyzji dotyczących przestrzennego zagospodarowania, jest bowiem jedynie tzw. aktem kierownictwa wewnętrznego, nie zaś aktem prawa miejscowego. Niemniej dokument ten jest wiążący przy opracowaniu miejscowych planów (art. 9). Nie jest też substytutem dawnych planów ogólnych, których opracowania i uchwalenia u.p.z.p. z 2003 r., niestety, nie przewiduje.

\subsection{Miejscowy plan zagospodarowania przestrzennego}

Ustalenie przeznaczenia terenu, także rozmieszczenie inwestycji celu publicznego oraz określenie sposobów zagospodarowania i warunków zabudowy terenu zawieraja, jak to już napisano, opracowywane i uchwalane miejscowe plany zagospodarowania przestrzennego (art. 4 ust. 1). Plany te nie sa wymagane dla całości obszaru gminy, a jedynie dla obszarów wskazanych przez władze gminy w studium oraz dla tych terenów, dla których opracowanie planów nakładają odrębne przepisy (art. 9 ust. 2). Choć ustawodawca nie przewiduje opracowywania planów zagospodarowania przestrzennego dla całości obszaru gminy, to jednak, jak się wydaje, nic nie stoi na przeszkodzie, aby tego rodzaju plany, jako szczególne przypadki planów miejscowych, opracowywać i uchwalać. Niejasna, dla autora tego tekstu, kwestią pozostaje natomiast to, czy taki dokument może być uznany za akt prawa miejscowego oraz czy w studium można obszar całej gminy wskazać jako przedmiot planu miejscowego. Od niedawna (po uchwaleniu ustawy o rewitalizacji, z 9 października 2015 r., Dz. U. poz. 1777) szczególną formą miejscowego planu zagospodarowania przestrzennego jest miejscowy plan rewitalizacji (art. 37a). W przypadku braku miejscowego planu zagospodarowania przestrzennego, a stopień pokrycia obszaru gmin planami miejscowymi jest bardzo różny, określenie sposobów zagospodarowania i warunków zabudowy terenu następuje w drodze administracyjnej decyzji o warunkach zabudowy i zagospodarowania terenu ${ }^{17}$. Lokalizacje inwestycji celu publicznego ustala się natomiast $\mathrm{w}$ drodze innego rodzaju decyzji administracyjnej, tj. decyzji o lokalizacji inwestycji celu publicznego (art. 4 ust. 2).

${ }_{17}$ P. Śleszyński et al., Stan zaawansowania planowania przestrzennego $w$ gminach, Prace Geograficzne 211, Instytut Geografii i Przestrzennego Zagospodarowania PAN, Warszawa 2007. 


\section{Tabela 2}

Charakterystyka polskiego systemu planowania wynikająca z zapisu ustawy z 27 marca 2003 r. o planowaniu i zagospodarowaniu przestrzennym

\begin{tabular}{|c|c|}
\hline $\begin{array}{c}\text { Cecha } \\
\text { charakterystyczna }\end{array}$ & Konsekwencje dla zagospodarowania przestrzennego \\
\hline Dwudzielczość & $\begin{array}{l}\text { Zagospodarowanie przestrzenne miasta prowadzone jest na podstawie } \\
\text { dwóch niespójnych dokumentów planistycznych o różnym i nielogicznym } \\
\text { statusie prawnym (studium uwarunkowań i kierunków zagospodarowa- } \\
\text { nia przestrzennego i miejscowy plan zagospodarowania przestrzennego) }\end{array}$ \\
\hline $\begin{array}{l}\text { Niekoncepcyjność } \\
\text { i asystemowość }\end{array}$ & $\begin{array}{l}\text { Brak obowiązku posiadania planu ogólnego zagospodarowania prze- } \\
\text { strzennego sprawia, że rozwój przestrzenny dokonuje się bez ogólnej } \\
\text { koncepcji struktury przestrzenno-funkcjonalnej miasta. Podmiotu } \\
\text { działań, czyli miasta, nie traktuje się, jako całości (systemu prze- } \\
\text { strzennego lub terytorialnego systemu społecznego) }\end{array}$ \\
\hline Wybiórczość & $\begin{array}{l}\text { Miejscowe plany zagospodarowania przestrzennego opracowuje się dla } \\
\text { dowolnych, z różnych względów wybranych obszarów miasta }\end{array}$ \\
\hline $\begin{array}{l}\text { Zbiurokratyzowanie } \\
\text { i sformalizowanie }\end{array}$ & $\begin{array}{l}\text { Przedmiot planowania i gospodarki przestrzennej traktuje się instru- } \\
\text { mentalnie, a jego przyszłe cechy (zagospodarowanie przestrzenne) okre- } \\
\text { śla jedynie w minimalnym zakresie rzeczowym, wynikajaccym z u.p.z.p. }\end{array}$ \\
\hline $\begin{array}{l}\text { Autarkiczność } \\
\text { i partykularyzm }\end{array}$ & $\begin{array}{l}\text { Dokumenty planistyczne opracowuje się tak, jakby miasto czy gmina } \\
\text { były jednostkami autarkicznymi. Nie uwzględnia się sąsiedztwa in- } \\
\text { nych jednostek terytorialnych, zwłaszcza sasiedztwa dużego miasta } \\
\text { (gmina jako składnik aglomeracji) }\end{array}$ \\
\hline $\begin{array}{l}\text { Krótkowzroczność } \\
\text { i doraźność }\end{array}$ & $\begin{array}{l}\text { Wydając decyzje przestrzenne, bierze się pod uwagę bieżący, doraźny } \\
\text { interes miasta (gminy), nie zaś dłuższą perspektywę czasową }\end{array}$ \\
\hline $\begin{array}{l}\text { Klientelizm } \\
\text { i pasożytniczy } \\
\text { charakter }\end{array}$ & $\begin{array}{l}\text { Miejscowe plany zagospodarowania opracowuje się przede wszystkim } \\
\text { pod potrzeby zgłaszane przez konkretnych inwestorów, bez zwracania } \\
\text { uwagi na strukturę przestrzenno-funkcjonalną miasta (gminy) i skut- } \\
\text { ki planowanego zagospodarowania }\end{array}$ \\
\hline $\begin{array}{l}\text { Manipulacyjność } \\
\text { i korupcjogenność }\end{array}$ & $\begin{array}{l}\text { Możliwość zagospodarowania terenu na podstawie administracyjnej } \\
\text { decyzji o ustaleniu warunków zabudowy umożliwia manipulacje w za- } \\
\text { kresie przeznaczenia terenu na określone cele }\end{array}$ \\
\hline Nieuspołecznienie & $\begin{array}{l}\text { Trudno jest zapisaną w u.p.z.p. możliwość składania uwag i protestów } \\
\text { do opracowanych dokumentów planistycznych uznać za uspołecznienie } \\
\text { procesu planowania i gospodarki przestrzennej }\end{array}$ \\
\hline Brak logiki działania & $\begin{array}{l}\text { W państwach Unii Europejskiej zagospodarowanie przestrzenne pro- } \\
\text { wadzi się zgodnie z zapisem planów, zarówno ogólnych, jak i szczegóło- } \\
\text { wych. Zagospodarowywany jest teren uzbrojony, z siecią dróg połączo- } \\
\text { nych z układem komunikacyjnym miejscowości. Jest to teren będący } \\
\text { w gestii władz lokalnych. Do konkretnego terenu, jego zapisanych } \\
\text { w planie ogólnym funkcji i zapisanych w planie szczegółowym zasad } \\
\text { gospodarowania, dostosować się muszą potencjalni inwestorzy, czego } \\
\text { pilnuje nadzór urbanistyczny. W Polsce o zagospodarowaniu prze- } \\
\text { strzennym decydują: właściciele gruntów oraz inwestorzy. Dla potrzeb } \\
\text { tych drugich ustala się warunki zabudowy lub opracowuje miejscowe } \\
\text { plany zagospodarowania }\end{array}$ \\
\hline Niekonstytucyjność & $\begin{array}{l}\text { Gospodarka przestrzenna prowadzona w sposób wynikajacy z u.p.z.p. } \\
\text { ani nie gwarantuje rozwoju zrównoważonego, ani utrzymania względ- } \\
\text { nie zaprowadzenia ładu przestrzennego, co jest sprzeczne z Konstytu- } \\
\text { cją RP oraz zapisem u.p.z.p. }\end{array}$ \\
\hline
\end{tabular}

Źródło: J. Parysek, Systemowy model planowania przestrzennego wyzwaniem dla gospodarki przestrzennej $w$ Polsce, w: S. Ciok, K. Janc (red.), Wspótczesne wyzwania polityki regionalnej i gospodarki przestrzennej, Rozprawy Naukowe Instytutu Geografii i Rozwoju Regionalnego Uniwersytetu Wrocławskiego, z. 32.2, Wrocław 2014, s. 9-24. 


\subsection{Ustalenie warunków zabudowy i zagospodarowania przestrzennego}

W przypadku braku miejscowego planu zagospodarowania przestrzennego zagospodarowanie takiego terenu, polegajace na lokalizacji obiektów zagospodarowania, wykonaniu innych robót budowlanych, zmianie sposobu użytkowania obiektu budowlanego lub jego części, wymaga ustalenia w drodze decyzji warunków zabudowy (art. 59 ust. 1). Decyzję o warunkach zabudowy wydaje wójt (burmistrz, prezydent miasta) po dokonaniu stosownych uzgodnień oraz uwzględnieniu odrębnych przepisów (art. 60 ust. 1). Wydanie decyzji o warunkach zabudowy jest możliwe jedynie w przypadku łącznego spełnienia następujących warunków (art. 61 ust. 1): „1) co najmniej jedna działka sassiednia, dostępna z tej samej drogi publicznej, jest zabudowana w sposób pozwalający na określenie wymagań dotyczących nowej zabudowy w zakresie kontynuacji funkcji, parametrów, cech i wskaźników kształtowania zabudowy oraz zagospodarowania terenu, w tym gabarytów i formy architektonicznej obiektów budowlanych, linii zabudowy oraz intensywności wykorzystania terenu; 2) teren ma dostęp do drogi publicznej; 3) istniejace lub projektowane uzbrojenie terenu, z uwzględnieniem ust. 5, jest wystarczające dla zamierzenia budowlanego; 4) teren nie wymaga uzyskania zgody na zmianę przeznaczenia gruntów rolnych i leśnych na cele nierolnicze i nieleśne albo jest objęty zgodą uzyskaną przy sporządzaniu miejscowych planów, które utraciły moc na podstawie art. 67 ustawy, o zagospodarowaniu przestrzennym z 1994 r., 5) decyzja jest zgodna z przepisami odrębnymi [...]". Sposób ustalania wymagań dotyczących nowej zabudowy i zagospodarowania terenu w przypadku braku planu miejscowego, określi w drodze rozporządzenia minister właściwy do spraw budownictwa, lokalnego planowania i zagospodarowania przestrzennego oraz mieszkalnictwa (art. 61 ust. 6).

Postanowienia ustawy dotyczace polityki przestrzennej i planowania przestrzennego w gminie są szczegółowe i bardzo rozbudowane i nie ma możliwości odnoszenia się do szczegółów w kontekście dość ogólnego celu niniejszego opracowania, który dotyczy konsekwencji stosowania postanowień tego dokumentu w gospodarce przestrzennej, a nie analizy prawnej.

\section{OCENA POLSKIEGO SYSTEMU PLANOWANIA I JEGO FUNKCJONOWANIA JAKO KONSEKWENCJI OBOWIĄZYWANIA USTAWY Z 27 MARCA 2003 R.}

Ustawa z 27 marca 2003 r. jest nieustannie nowelizowana, a właściwie rozszerzana o nowe szczegółowe zapisy wprowadzające istotne, choć czasami nie wiadomo, czemu mające służyć, zmiany. Ważniejsze ostatnio wprowadzone zmiany i uzupełnienia dotyczyły m.in.: wprowadzenie audytu krajobrazowego, zastapienie planu zagospodarowania przestrzennego obszaru metropolitalnego planem zagospodarowania przestrzennego miejskiego obszaru funkcjonalnego ośrodka wojewódzkiego, wprowadzenie ramowego studium uwarunkowań i kierunków zagospodarowania przestrzennego (obszaru) związku 
metropolitalnego czy też wprowadzenie, jako szczególnej formy planu miejscowego, miejscowego planu rewitalizacji. Jest oczywiście cały szereg innych zmian, które obowiąujące $\mathrm{w}$ danym momencie regulacje prawne czynią coraz bardziej detalicznymi, zawiłymi, niejasnymi, komplikującymi proces planowania i przyjęcia sensownych rozwiązań w kwestach spornych. To systematyczne powiększanie zakresu zapisu ustawy czyni też rzeczą praktycznie niemożliwa dokonanie bardziej szczegółowej charakterystyki skutków działania polskiego systemu planowania przestrzennego, jak również dokonanie krytycznej oceny samego modelu systemu planowania przestrzennego funkcjonującego pod rządami ustawy z 27 marca 2003 r., zwłaszcza kiedy niemal co chwilę mamy do czynienia z nową materia prawną (permanentna nowelizacja u.p.z.p.) ${ }^{18}$. Niezależnie od tych zmian od kilku już lat wielu autorów przedstawia krytyczną ocenę polskiego systemu planowania i jego funkcjonowania, której istotne aspekty zestawiono w tabeli 2 (s. 48).

Analizujac różne opinie na temat polskiego systemu planowania przestrzennego funkcjonującego pod rządami ustawy z 2003 r., odnoszace się nie tyle do całego systemu, ile do planowania na szczeblu lokalnym, można zauważyć dwie ich kategorie: pozytywne i negatywne. Autorami opinii pozytywnych sa przede wszystkim: osoby czynnie zaangażowane w procedury planistyczne, niektórzy przedstawiciele władz samorządowych, właściciele nieruchomości gruntowych, deweloperzy budownictwa mieszkaniowego, poważny kapitał inwestycyjny, spekulanci na rynku nieruchomości, a także prawnicy. Osoby profesjonalnie wykonujące opracowania planistyczne uważają polski system planowania przestrzennego za bardzo racjonalny, jednak - jak się wydaje przede wszystkim z uwagi na zakres rzeczowy dokumentów planistycznych, a nie konsekwencje stosowania u.p.z.p. Jeśli coś hamuje i ogranicza prawidłowe funkcjonowanie systemu, to sa to politycy, inwestorzy oraz prawo własności. Oceny takie formułowane są często na podstawie opinii wyrażanych w niektórych mediach ${ }^{19}$. Trudno nie podzielić tej ostatniej opinii dotyczacej hamulców i ograniczeń planowania, jest jednak to, jak się wydaje, opinia utrudniajacca i komplikująca raczej życie planistom. Nie stawia się bowiem pod znakiem zapytania możliwości realizacji podstawowych celów gospodarki przestrzennej, zwłaszcza takich, jak ład przestrzenny i rozwój zrównoważony. Nie podkreśla się słabości regulacji prawnych sprzyjających partykularnej możliwości ich interpretacji. Tego rodzaju opinie i oceny prezentuja, niestety, także przedstawiciele środowisk naukowych, w tym zwłaszcza zaangażowani w prace planistyczne i projektowe, mają bowiem własne zespoły wykonawcze. Tego rodzaju absorbujacca aktywność nie może, co jest oczywiste, sprzyjać ich naukowemu zaangażowaniu, zwłaszcza w zakresie teorii i metodologii gospodarki przestrzennej ${ }^{20}$. Profesja planistyczna tych osób konsekwentnie nie skła-

\footnotetext{
${ }_{18}$ Zwięzła charakterystyka systemu planowania przestrzennego w nawiązaniu do stosunkowo skromnych rozmiarów ustawy z 1994 r. o zagospodarowaniu przestrzennym wypełniła tekstem 226 stron cytowanej uprzednio publikacji Z. Niewiadomskiego.

${ }^{19} \mathrm{I}$. Mironowicz, The state of the art of planning in Europe, „disP - The Planning Review” 51(1), 2015, s. 60-61.

${ }^{20}$ Ibidem.
} 
nia do krytycznej oceny funkcjonującego modelu planowania przestrzennego w Polsce choćby z tego powodu, że instrumentalne i sformalizowane podejście do procesu planowania oraz szerokie możliwości interpretacji treści u.p.z.p. (zwłaszcza w planowaniu na poziomie gminnym), tworzą warunki do stosunkowo szybkiego przygotowania dokumentów planistycznych, często w wersji metodą „na żądanie” (inwestora, władz samorządowych, generalnie podmiotu płacącego za usługę projektowa), tworząc przy tej okazji warunki do korzystnego ukształtowania relacji nakłady-efekty, w czym, co jest zresztą zrozumiałe, zainteresowani sa profesjonalni planiści.

Przedstawicielom władz samorządowych obowiązujace regulacje prawne umożliwiają wypełnianie nałożonego ustawowo obowiązku zabezpieczenia zbiorowych potrzeb wspólnoty, co ułatwiają i nowe w gminie podmioty gospodarcze (miejsca pracy, wynagrodzenia, poprawa warunków obsługi, inwestycje w sferze infrastruktury komunalnej itp.), i nowi mieszkańcy (podatnicy, kapitał społeczny), choć ci ostatni są często utrapieniem dla władz. Z drugiej jednak strony otwierają możliwości realizacji polityki przestrzennej niezgodnej z interesem ogólnospołecznym, a sprzyjajaccej interesowi zainteresowanych podmiotów wraz z tworzeniem warunków do rozwiązań korupcyjnych.

Właścicielom nieruchomości gruntowych zapisy u.p.z.p. umożliwiają uzyskanie zakładanego efektu finansowego na rynku nieruchomości, zwłaszcza w sytuacji dużego zapotrzebowania na grunty pod zabudowę. Mało restrykcyjne zapisy (administracyjna decyzja ustalenia warunków zabudowy i zagospodarowania) sprzyjaja najpierw łatwemu i taniemu pozyskaniu przez deweloperów działek na cele budowlane (bez uwzględnienia konsekwencji dla przyszłych mieszkańców), następnie uzyskaniu zgody na zabudowę, a w konsekwencji - maksymalizację efektu ekonomicznego z $1 \mathrm{~m}^{2}$ zakupionego i zainwestowanego terenu. Poważny kapitał inwestycyjny może zaś praktycznie nabyć odpowiedni do potrzeb teren inwestycyjny w wielu miejscach, zwłaszcza kiedy niecałe obszary gmin „pokryte sa” miejscowymi planami zagospodarowania przestrzennego i gdy budżety gmin są nad wyraz skromne.

Sytuacja niedoskonałego prawa otwiera, co jest oczywiste, szerokie pole działań spekulacyjnych w zakresie obrotu nieruchomościami i praktyk korupcyjnych. Zawiłość i niejednoznaczność prawa gospodarki przestrzennej wymaga zaś fachowej interpretacji jego postanowień, zwłaszcza kiedy praktycznie, na drodze prawnej, uzyskać można w zasadzie każdą decyzję lokalizacyjna i każdą odmowę zakwestionować, przede wszystkim dla inwestycji na terenach nieobjętych planem. Sytuacja ta otwiera zatem szeroki rynek porad prawnych, który wzbogacają inne kwestie sporne i konflikty na tle użytkowania ziemi, będące efektem słabości prawa gospodarki przestrzennej. Gospodarka przestrzenna jest więc nie tylko stosunkowo nowym, ale ciagle poszerzajacym się, na skutek złych regulacji i nieustannych nowelizacji, segmentem rynku pracy prawników, specjalistów od prawa gospodarki przestrzennej.

Do krytyków struktury, organizacji i funkcjonowania polskiego systemu planowania przestrzennego należą przede wszystkim środowiska naukowe (zwłaszcza osoby zajmujące się teorią i metodologią gospodarki przestrzennej oraz problematyką rozwoju społeczno-gospodarczego, gospodarką miejska, ekonomika miejska, funkcjonowaniem miast i aglomeracji oraz procesami ur- 
banizacji, zagadnieniami rewitalizacji itp.), niektórzy przedstawiciele władz samorządowych (przede wszystkim dużych średnich miast) oraz inne osoby i organizacje $\mathrm{e}^{21}$. Krytyczny punkt widzenia na polski system planowania i jego funkcjonowanie prezentują ponadto osoby o dużym, międzynarodowym doświadczeniu i dorobku w zakresie szeroko rozumianego planowania, w tym także niektórzy planiści - praktycy związani z wyższymi uczelniami. Są to jednak przede wszystkim takie osoby, które potrafia, z jednej strony, krytycznie spojrzeć na polska gospodarkę przestrzenna, a z drugiej - racjonalnie połaczyć działalność naukową z praktyka, przede wszystkim w zakresie oceny i opiniowania opracowań planistycznych.

\section{ZAGOSPODAROWANIE PRZESTRZENNE JAKO KONSEKWENCJA STOSOWANIA ZAPISÓW U.P.Z.P.}

Dla wskazania skutków, jakie w zagospodarowaniu przestrzennym powoduje stosowanie u.p.z.p. z 2003 r., ważne jest podniesienie pozytywnych i negatywnych stron jej postanowień oraz konsekwencji stosowania.

Odejście od „Koncepcji polityki przestrzennego zagospodarowania kraju” i przyjęcie, jako dokumentu określającego politykę przestrzenną państwa, bardziej treściwej „Koncepcji przestrzennego zagospodarowania kraju 2030” (tzw. KPZK), ocenić należy generalnie pozytywnie ${ }^{22}$. Zawarta w Koncepcji wizja struktury przestrzenno-funkcjonalnej Polski jest bardziej konkretna i klarowna, jednakże przede wszystkim dzięki mapom zamieszczonym na końcu drukowanej wersji. Mimo zmiany nazwy i innych, w sumie dobrych zmian, jest to jednak nadal, jak się wydaje, przede wszystkim materiał przygotowany dla celów realizacji polityki przestrzennej na poziomie krajowym. W tym kontekście docelowym rozwiązaniem powinien być „plan krajowy”. Taki dokument, choć może kojarzyć się z niechlubną przeszłością starego ustroju, to jednak był produktem najlepszych lat planowania przestrzennego w Polsce. Składnikami takiego planu mogłyby być załączone do aktualnej koncepcji mapy będące efektem prowadzonych prac badawczych ${ }^{23}$. Poważne wątpliwości budzi, wspo-

${ }^{21}$ A. Billert, Planowanie przestrzenne a polityka. Trzecia droga do trzeciego świata, w: T. Ossowicz, T. Zipser (red.), Urbanistyka $w$ działaniu. Teoria i praktyka. Materiały II Kongresu Urbanistyki Polskiej, Biblioteka Urbanisty, Urbanista 9, Warszawa 2006, s. 240-253; J. Parysek, op. cit.; A. Jędraszko, Gospodarka przestrzenna w Polsce wobec standardów europejskich, Biblioteka Urbanisty, Urbanista 13, Warszawa 2008; Z. Ziobrowski, Polityka przestrzenna a decyzje o warunkach zabudowy oraz Spatial policy and the planning permits. Referaty wygłoszone na konferencji poświęconej współzależności ustaleń - studium uwarunkowań - i kierunków zagospodarowania przestrzennego oraz miejscowych planów zagospodarowania przestrzennego. Kraków 2009. Materiały konferencyjne, s. 21-27; J. Parysek, Urban development policy of the European Union and the discretionary nature of Polish spatial planning, w: P. Churski, W. Ratajczak (red.), Regional Development and Regional Policy in Poland: First Experiences and New Challenges of the European Union Membership, Part I, KPZK PAN, Studia Regionalia 27.1, Warszawa 2010, s. 172-184.

${ }_{22}$ Autor niniejszego opracowania nie pretenduje w tym miejscu do roli recenzenta KPZK, ocena przyjętego przez Radę Ministrów 13 grudnia 2011 r. dokumentu nie była bowiem przedmiotem szczególnego zainteresowania.

${ }^{23}$ Mapy wykonane zostały w Instytucie Geografii i Przestrzennego Zagospodarowania PAN przez zespół pracujący pod kierunkiem P. Śleszyńskiego. 
mniana już uprzednio, mania wprowadzania nowych pojęć, które nie wnosząc niczego nowego i dobrego, wprowadzają mętlik terminologiczny. Przykładowo nie wiadomo, czemu służyć ma wydzielenie w KPZK obszarów funkcjonalnych, jako przedmiotu gospodarki przestrzennej, kiedy cały kraj pokrywa sieć nakładających się na siebie obszarów, niekoniecznie funkcjonalnych (konkretnie funkcjonalnych obszarów oddziaływania miast i strukturalnych obszarów wiejskich). W naukach przestrzenno-ekonomicznych obszarami funkcjonalnymi sa regiony węzłowe - i za takie uznać można, w nawiązaniu do KPZK, obszary oddziaływania wybranych ośrodków miejskich. Jakimi zatem obszarami funkcjonalnymi są tereny wiejskie, bez względu na to, czy uczestnicza w procesach rozwojowych czy też nie, zwłaszcza kiedy pokrywają cały obszar kraju i kiedy obszary takie znajdują się w strefach oddziaływania ośrodków miejskich (innych obszarów funkcjonalnych)? Nie wiadomo, dlaczego zostały z dokumentów planistycznych usunięte obszary problemowe (które mogły pełnić i pełniły różne funkcje) i zastapione funkcjonalnymi. Nie każdy obszar funkcjonalny jest problemowym i nie każdy problemowy - funkcjonalnym. Jest też pewna różnica między obszarem funkcjonalnym a pełniącym funkcje. W teorii regionu ekonomicznego region węzłowy jest funkcjonalnym, a jednorodny - strukturalnym, choć może pełnić funkcje np. przemysłowe, rolnicze, turystyczne itp. Oczywiście zarówno region funkcjonalny, jak i strukturalny może być problemowym. Zaproponowany dychotomiczny podział obszaru kraju na miasta (także strefy ich wpływów, czyli obszary funkcjonalne) i wieś (wiejskie obszary funkcjonalne) przy zróżnicowaniu struktury przestrzenno-funkcjonalnej kraju, co bardzo dobrze dokumentują mapy załączone na końcu KPZK, jest, mając na względzie realizację polityki przestrzennej państwa, nieporozumieniem ${ }^{24}$. Takich dyskusyjnych propozycji jest wiele, a ich dostrzeżenie nie wymaga zbyt wnikliwego studiowania tego dokumentu.

Dobrze ocenić należy zakres rzeczowy wojewódzkich planów zagospodarowania jednak ich rola $\mathrm{w}$ realizacji polityki przestrzennej państwa, zagospodarowaniu województw oraz planowaniu na szczeblu lokalnym powinna być jeszcze bardziej podkreślona. Dziwnym pomysłem jest zastapienie planu zagospodarowania przestrzennego obszaru metropolitalnego planem zagospodarowania przestrzennego miejskiego obszaru funkcjonalnego ośrodka wojewódzkiego. Samo pojęcie obszaru metropolitalnego w zasadzie nie znika, choć przybiera postać związku metropolitalnego, dla którego nie jest opracowywany plan, a studium uwarunkowań i kierunków zagospodarowania przestrzennego. Pojawia się jednak nowy, nie wiadomo, dlaczego nieznany uprzednio termin: „obszar funkcjonalny ośrodka wojewódzkiego", kiedy od dawna znane są i stosowane pojęcia: ,aglomeracja” i „region miejski”. To dla takich obszarów powinny być opracowywane plany zagospodarowania przestrzennego jako części planów wojewódzkich ${ }^{25}$. Zapisa-

${ }^{24}$ To tylko jeden z przykładów słabości opracowanej Koncepcji (KPZK 2030), jaki dokumentuje ryc. 40 na s. 196 przytaczanego dokumentu rządowego.

${ }^{25}$ A. Wróbel, Pojęcie regionu geograficznego a teoria geografii, Prace Geograficzne IG PAN 48, Warszawa 1965; K. Dziewoński, Teoria regionu ekonomicznego, „Przegląd Geograficzny” 39(1), 1967, s. 33-50; Z. Chojnicki, T. Czyż, Metody taksonomii numerycznej w regionalizacji geo- 
ne w u.p.z.p. zadanie (opracowanie planów zagospodarowania obszaru funkcjonalnego ośrodka wojewódzkiego) prawdopodobnie wykluczy obligatoryjne opracowywanie planów zagospodarowania przestrzennego innych aglomeracji (poza aglomeracjami miast wojewódzkich), co w sytuacji ciagle postępującej suburbanizacji nie jest dobra zamiana. Uchwalenie przez samorządowe władze wojewódzkie planu zagospodarowania przestrzennego aglomeracji byłoby znacznie lepszym rozwiązaniem, wzmacniającym planowanie na szczeblu regionalnym, co jest zresztą zgodne z polityką regionalną Unii Europejskiej. Byłoby także przejawem decentralizacji decyzji w zakresie gospodarki przestrzennej. Nie wiadomo, jakie intencje przyświecały wprowadzeniu audytu krajobrazowego, jako obligatoryjnego dokumentu poprzedzajacego opracowanie planu zagospodarowania przestrzennego województwa, w sytuacji kiedy aspekt środowiskowy wykonywanych planów jest w wystarczającym stopniu podkreślany w zapisach u.p.z.p., a studia do planu (studia, analizy, koncepcje, programy), w tym także dotyczące środowiska, należą do tradycyjnej praktyki planistycznej wojewódzkich biur planowania przestrzennego (art. 38). Pozostawienie zakresu rzeczowego audytu władzom samorządowym województwa byłoby kolejnym przejawem decentralizacji decyzji w zakresie gospodarki przestrzennej, wzmocnieniem podmiotowości społeczności regionalnej (sejmiku) w tym zakresie oraz docenieniem wiedzy i kompetencji planistów regionalnych służb planowania przestrzennego. Ustawa powinna zawierać jedynie zasadnicze ustalenia dotyczące rzeczowego zakresu zarówno planu zagospodarowania przestrzennego województwa, jak i audytu krajobrazowego (w przypadku utrzymania tego dokumentu), pozostawiając szczegóły władzom regionalnym ${ }^{26}$. W ten sposób z Rady Ministrów oraz odpowiedniego dla gospodarki przestrzennej ministra resortowego zdjęto by obowiązek przygotowywania rozporządzeń zawierających uszczegółowienie zakresu rzeczowego opracowywanych dokumentów, co ponadto byłoby działaniem na rzecz ograniczenia biurokracji. Trudno jest ocenić, jak dokonane w ostatnich kilku latach i miesiącach zmiany ustawowe wpłyną na proces planowania na szczeblu regionalnym i krajowym, przede wszystkim na jego efektywność i skuteczność, oceniane z punktu widzenia interesu państwa i ogólnospołecznego interesu mieszkańców regionów.

Zastanawia brak podmiotowości władz powiatowych w zakresie gospodarki przestrzennej. Powiat jest tą jednostką terytorialna, która w sposób szczególny jawi się, jako potencjalny podmiot prowadzenia nie tylko sensownej lokalnej gospodarki przestrzennej, ale także gospodarki lokalnej w ogóle. Należy

graficznej, PWN, Warszawa 1973; P. Korcelli, Regiony miejskie w systemie osadniczym Polski, w: K. Dziewoński, P. Korcelli (red.), Studia nad migracjami i przemianami systemu osadniczego $w$ Polsce, Prace Geograficzne, IGiPZ PAN, 140, Warszawa 1981, s. 189-212; J. Parysek, Modele klasyfikacji w geografii, Geografia 31, WN UAM, Poznań 1982; P. Śleszyński, Delimitacja miejskich obszarów funkcjonalnych stolic wojewódzkich, „Przegląd Geograficzny” 85(2), 2013, s. $173-197$.

${ }^{26}$ Zakres rzeczowy zapisany w art. 38a dotyczacy audytu krajobrazowego oraz w art. 39 dotyczący planu zagospodarowania przestrzennego województwa jest, jak się wydaje, całkowicie wystarczający. Uzupełnienie zakresu powinno zaś nawiązywać do specyfiki województwa będącego przedmiotem planu oraz wynikać z konkretnych potrzeb. 
zatem poważnie przemyśleć sens przekazania samorządom powiatowym kompetencji w zakresie planowania rozwoju społeczno-gospodarczego, gospodarki przestrzennej oraz użytkowania środowiska.

Najwięcej niekorzystnych zmian w zagospodarowaniu przestrzennym powoduje jednak u.p.z.p. z 2003 r. na tym szczeblu administracji terytorialnej, na którym podejmuje się decyzje o zagospodarowaniu przestrzennym, tj. gminnym. Ustawa o planowaniu i zagospodarowaniu przestrzennym (art. 1 ust. 1 określa: „1) zasady kształtowania polityki przestrzennej przez jednostki samorządu terytorialnego i organy administracji rządowej 2) zakres i sposoby postępowania w sprawach przeznaczania terenów na określone cele oraz ustalania zasad ich zagospodarowania i zabudowy - przyjmując ład przestrzenny i zrównoważony rozwój za podstawę tych działań”. Niestety, w zagospodarowaniu przestrzennym często trudno jest się doszukać i ładu przestrzennego, i rozwoju zrównoważonego. Łatwo jest natomiast wskazać na chaos w tym zakresie. Jest kilka przyczyn takiego stanu rzeczy (chaos, brak zrównoważenia w zagospodarowaniu przestrzennym) o szczególnym, jak się wydaje, znaczeniu, niekiedy powiązanych z sobą.

Pierwszą przyczyną jest brak ogólnych planów zagospodarowania przestrzennego gmin, co oznacza, że gmina, jako całość będąca terytorialnym systemem społecznym, nie jest przedmiotem planowania i gospodarki przestrzennej. Plany zagospodarowania przestrzennego opracowywane i uchwalane są przede wszystkim dla wskazanych w studium uwarunkowań i kierunków zagospodarowania przestrzennego obszarów lub innych (uważanych przez władze lokalne za ważne). Planem ogólnym zagospodarowania przestrzennego nie jest studium, które nie jest aktem prawa lokalnego, a jedynie tzw. dokumentem kierownictwa wewnętrznego. Wprawdzie w metodologii planowania przestrzennego czasami zakłada się wykonywanie dwóch kategorii dokumentów, jednak zawsze są to: (1) studia do planów oraz (2) plany zagospodarowania przestrzennego, zarówno ogólne, jak i szczegółowe. W polskim systemie planowania przestrzennego plany ogólne w 2005 r. gdzieś zniknęły. Przecież struktura przestrzenna całości (także jej ład i zrównoważenie) nie będzie nigdy sumą indywidualnie kształtowanych części. W istniejącej sytuacji aktualne pozostaje pytanie, czego ma dotyczyć ład przestrzenny i rozwój zrównoważony - gminy czy zagospodarowywanego terenu. Dla wielu podmiotów (osób) tego rodzaju sytuacja jest jednak niezwykle wygodna, umożliwia bowiem, na podstawie planu miejscowego lub decyzji administracyjnej, realizację partykularnego interesu. Ustawodawca prawdopodobnie zapomniał o tym, że gmina jest funkcjonalną całością i że nie można kształtować jej przestrzennej organizacji, struktury i funkcjonowania bez stosownego modelu tej całości, jakim jest plan ogólny.

Konsekwencją zapisów u.p.z.p. jest nie tylko brak planów ogólnych zagospodarowania przestrzennego gmin, ale także brak kompletnego pokrycia gminy miejscowymi planami zagospodarowania przestrzennego, co prowadzi do usankcjonowania istnienia i funkcjonowania administracyjnej drogi zagospodarowania terenu. Tak zwane ustalenie warunków zabudowy i zagospodarowania, które miało być rozwiązaniem wyjątkowym, stało się powszech- 
nie stosowana praktyką i jest druga przyczyną obserwowanego stanu rzeczy. Praktycznie oznacza możliwość przeznaczenia każdego terenu na niemal każdy cel, wraz z jego konkretną zabudową. Zapisane w u.p.z.p. warunki (5 warunków), jakie należy spełnić przy ubieganiu się o taką decyzję, są możliwe do spełnienia niemal w każdej sytuacji, a prawo do ubiegania się o taką decyzję i jej uzyskanie jest w stanie uzasadnić każdy prawnik majacy pojęcie o prawie gospodarki przestrzennej (art. 61 ust. 1). To ten zapis ustawowy, obok braku planu ogólnego i kompletu miejscowych planów, generuje chaos w zagospodarowaniu przestrzennym miast i gmin i sprawia, że nie społeczność lokalna i działające w jej imieniu władze samorządowe, a właściciele nieruchomości, deweloperzy budownictwa mieszkaniowego, inwestorzy, spekulanci gruntami, konsorcja projektowo-budowlano, a także, niestety, nieodpowiedzialni przedstawiciele władz lokalnych oraz działający na konkretne zamówienie prywatni planiści kształtują struktury przestrzenno-funkcjonalne jednostek osadniczych ${ }^{27}$. Nie bez znaczenia dla efektów gospodarki przestrzennej są finansowe obciążenia gmin z tytułu opracowania planów oraz ponoszenia kosztów realizacji uchwalonych planów (wprowadzanie planów w życie). Wiele dysponujacych skromnym budżetem gmin nie jest w stanie sfinansować pełnego pokrycia planami obszaru gminy, zwłaszcza zaś ponoszenia kosztów realizacji planów, przy stosunkowo niskich przychodach z tego tytułu (opłata planistyczna, opłata adjacencka, dochody z własnego majątku na obszarze objętym planem). Do opracowywania planów zniechęca także wysoki koszt budowy sieci infrastruktury oraz konieczność wykupu gruntów pod inwestycje celu publicznego. W tej sytuacji albo nie uchwala się planów, albo koszty opracowania planów pokrywają inwestorzy. Ci zaś chętnie sfinansują opracowanie planu, jaki leży w ich interesie, lub będą starać się o uzyskanie administracyjnej decyzji o warunkach zabudowy i zagospodarowaniu terenu. Jest rzeczą oczywista, że tego rodzaju regulacje prawne nie sprzyjają realizacji interesu ogólnospołecznego, a interesowi prywatnego inwestora i dodatkowo tworzą pokusę korupcji.

\section{ZAKOŃCZENIE}

W świetle dokonanej analizy uzasadniony wydaje się ten punkt widzenia, który odpowiedzialnością za stan zagospodarowania przestrzennego, zwłaszcza za brak ładu przestrzennego, zrównoważenia rozwoju oraz prymat w gospodarce przestrzennej interesu indywidualnego nad ogólnospołecznym obarcza obowiąujace regulacje prawne. Regulacje dalekie od prostych, jasnych, przejrzystych, jednoznacznych, ramowych oraz stałych w czasie. Nieustannie nowelizowana ustawa lansuje instrumentalny model planowania (który działa jak instrukcja składania mebli konsorcjum IKEA), czyniąc procedury planistyczne coraz bardziej skomplikowanymi i w wysokim stopniu

27 J. Parysek, Urban development..., s. 172-184. 
zbiurokratyzowanymi. Uchwalanie innych ustaw mających związek z gospodarką przestrzenną sprawia zaś, że nie dokument uchwalony w $2003 \mathrm{r}$., a także wiele innych, określa dziś ramy możliwych rozwiązań przestrzennych (np. ustawy o rewitalizacji i o związkach metropolitalnych, powodujące daleko idąca nowelizację ustawy o planowaniu i zagospodarowaniu przestrzennym).

Każda nowelizacja, zwłaszcza szybko dokonana, tworzy warunki do wprowadzenia zasadniczych, kolejnych, pozbawionych większego sensu zmian, jak np. zastapienie planu zagospodarowania przestrzennego obszaru metropolitalnego ramowym studium uwarunkowań i kierunków zagospodarowania przestrzennego związku metropolitalnego, a także wprowadzenie planu zagospodarowania przestrzennego obszaru funkcjonalnego miejskiego ośrodka wojewódzkiego oraz wojewódzkiego audytu krajobrazowego. Nie wiadomo też, jaki jest sens wprowadzenia nowej terminologii obszarów będących przedmiotem planowania, gdy od dawna funkcjonuja jasne, dobrze zdefiniowane pojęcia: „,aglomeracja” i „obszar problemowy”. Na domiar złego to nie władze regionalne (wojewoda, marszałek), a Rada Ministrów lub odpowiedni resort mają wyznaczać granice obszarów planowania oraz określać szczegółowo zakres rzeczowy poszczególnych dokumentów dotyczących przecież całkiem innych pod względem warunków przyrodniczych, struktury ukła$\mathrm{du}$ osadniczego, sytuacji demograficznej, poziomu rozwoju gospodarczego, struktury gospodarczej, zagospodarowania przestrzennego, potencjalnych warunków rozwoju oraz położenia geograficznego, obszarów.

Wydaje się, że wszelkie możliwe nowelizacje złej ustawy o planowaniu i zagospodarowaniu przestrzennym z 27 marca 2003 r. zostały dawno wyczerpane. Potrzebna jest napisana od nowa „ustawa o gospodarce przestrzennej”, generalna, jasna, jednoznaczna, ramowa, trwała w czasie, oparta na teorii i metodologii gospodarki przestrzennej, uwzględniająca, zgodnie ze standardami europejskimi, autonomię władz regionalnych, w zakresie którego dotyczy, nawiązująca do dawnej, dobrej tradycji w dziedzinie planowania przestrzennego, przywracająca plan krajowy, regionalne i powiatowe plany zagospodarowania przestrzennego (także aglomeracji miejskich) składające się z części analitycznej (zastępującej studium) i planistycznej oraz ogólne i szczegółowe (miejscowe) plany zagospodarowania przestrzennego gmin. Ustawa, która zgodnie z decentralizacją kompetencji odtworzy służby planowania rozwoju w jednostkach administracji samorządowej, gdyż tylko takie rozwiązania zagwarantować moga respektowanie stanowionego prawa, a wraz z nim ogólnospołeczny interes zagospodarowania przestrzennego, czego przejawem będą i ład przestrzenny, i rozwój zrównoważony,

prof. dr hab. Jerzy J. Parysek

Uniwersytet im. Adama Mickiewicza w Poznaniu

parys@amu.edu.pl 


\section{ASKING ABOUT THE FUTURE OF SPATIAL MANAGEMENT IN POLAND \\ (13 YEARS AFTER THE ENFORCEMENT OF THE 2003 LEGAL REGULATION)}

\section{Sum mary}

Thirteen years of spatial economy carried out in Poland pursuant to the Act on Spatial Planning and Development of 27 March 2003 have been long enough for evaluation of the functioning of the Polish spatial planning system and the effects of the regulation on spatial management. Such an assessment is important to be made particularly in the light of a new law being drafted to regulate spatial planning. This, however, will only add to the complexity and little efficiency of the existing laws, currently being a result of multiple amendments made in recent years to the Act in force today. In this paper, a general reconstruction of the Polish spatial management Act has been made and the planning documents that shape spatial management presented. A discussion of the functioning of spatial management in the context of the regulations currently binding follows and an assessment of the status quo of the spatial management as a result of the existing regulation is offered. In the concluding remarks, certain recommendations and suggestions of measures to be taken to improve the current situation have also been made. 